\title{
OPPORTUNITIES AND CHALLENGES OF HALAL PRODUCT BUSINESS PASCA COVID- 19 IN INDONESIA
}

\author{
Zainal Arif, Efri Syamsul Bahri, Zulfitria \\ Islamic Banking Universitas Muhammadiyah Tangerang, \\ Islamic Acounting SEBI, Education Technology Universitas Muhammadiyah \\ Jakarta \\ zarifpambon@gmail.com,efri.sb@sebi.ac.id,zulfitria81@gmail.com
}

\begin{abstract}
This study aims to examine the halal business opportunities and challenges in Indonesia pasca pandemi COVID-19. This research uses descriptive qualitative method by using documentation data in the form of books, reports from official institutions such as BPS, OJK, BI, Ministry of Trade, Kemenpan and scientific journals. The results of a study of several literatures found that Indonesia actually has a huge opportunity to become the center of the world's halal business. This can be seen from several indicators between the high level of the Muslim population and the high level of consumption. However, the attitude of business actors who tend to be unaware, pursue more profits, lack of government attention, protect business players more than consumers, the low public response to halal products is a major obstacle. The main solution is to accelerate the application of the JPH (Halal product guarantee) Law as a legal umbrella, awareness of entrepreneurs and business people, by making halal certification a part of excellent service, and community support.
\end{abstract}

Keywords: Halal Product, Business, Opportunities, Challenges, Pasca COVID-19

\section{A. Introduction}

The Indonesian government officially announced a confirmed case of COVID19 infection in Indonesia on March 2, 2020 and WHO, the UN health agency, declared COVID-19 a global pandemic on March 11, 2020. The spread of the Corona virus is very fast-exponential because as of May 9, 2020 it has spread to 212 countries, infected 4,029,543 people and caused 276,484 deaths, within 4 months since the infection was first discovered in Wuhan, China on December 31, 2019. To break the chain of spreading the virus, governments in various countries have adopted various restriction policies. human movement in the form of lockdowns, semi- 
lockdowns, and large-scale social barriers. At this time, human health and safety are the main things ${ }^{1}$. In Indonesia, almost all activities that involve physically gathering people during the pandemic are prohibited. The government closed schools, offices, factories, public services, places of worship, malls, restaurants and also tourist areas. This policy resulted in the cessation of many economic activities and resulted in disruption of the supply chain and the production of goods and services. ${ }^{2}$ As the country with the largest Muslim population in the world, the question arises how does Islam play a role in tackling and overcoming the impact of the COVID-19 pandemic? What is the economic impact of Covid-19 on the Indonesian people, who are predominantly Muslim? And how does the Islamic concept of economy and finance respond and provide solutions to the COVID-19 pandemic, especially the halal industry? To answer this question, the paper will attempt to analyze various primary sources from various related institutions and secondary sources regarding the economic impact and economic response of sharia, especially the opportunities and challenges of halal business in Indonesia. This paper argues that COVID-19 has had a huge economic impact in Indonesia, and the sharia economy is playing a positive role in overcoming this impact. In fact, COVID-19 can become a momentum for the revival of the sharia economy in the country as long as the sharia economy is able to transform into a sustainable and digital-based sharia economy. In the first part, this paper describes the halal product business and its development in Indonesia. In the next section, this paper will analyze the impact of COVID-19 on the economic sector and continue with the potential for the halal business to be followed by halal business opportunities, further challenges and obstacles to the halal business in Indonesia. And finally the paper will close with a conclusion.

Eating halal food is a basic right of every Muslim. This is not only related to religious beliefs, but there are health, economic and safety dimensions. So with a majority Muslim population, without being asked, the state should be present to protect its citizens in the fulfillment of their citizens' fundamental rights. In line with that, businesses (producers) should also provide protection to consumers. For this purpose, the more active role of the state in the regulation of the economic system is demanded which is spelled out in the strategies undertaken by the government / country in carrying out trade / business instruments including through regulation. ${ }^{3}$

\footnotetext{
1 Nur Hidayah, "Covid-19," in Covid-19 Wabah, Fitnah Dan Hikmah, vol. 1 (Amma Alamia, 2020), 379.

2 Hidayah.

3 Asep Syarifuddin Hidayat And Mustolih Siradj, "Sertifikasi Halal Dan Sertifikasi Non Halal," AHKAM : Jurnal Ilmu Syariah 15, no.
} 2 (2015): 199-210, https://doi.org/10.15408/ajis.v15i2.2864. 
Halal lifestyle ${ }^{4}$ lately it is indeed sweeping the world, not only symptomatically in countries with a Muslim majority but also in a country with a non-Muslim majority population ${ }^{5}$. Awareness of the fulfillment of halal food increases in the global arena along with the stretching of global halal tourism which is not merely limited to the tourist destination sector which is linked to Islamic sites (religious) but involves the fulfillment of the needs of tourism itself. ${ }^{6}$ Global-scale companies (multinational corporation) currently has implemented a halal system, say, such as Japan Airlaines, Singapore AirLines, Qantas, Chatay Pacific (Hong Kong), America Airlines provides a halal menu (moslem meal). This symptom also spreads to America, Australia, Japan, China, India, and Latin American countries. Especially for Japan, this country has a very serious attention to the development of halal trends, one of the indications is the convening of Japan Halal Expo which is always crowded so that it is quite successful in drawing attention and interest of various parties. Japan Halal Expo is a large-scale exhibition containing halal products made in Japan. ${ }^{7}$ Noted, currently there are already 350 restaurants in Japan that have provided halal food, 54 of which are specialty restaurants of the country's food. ${ }^{8}$

The word halal has become public consumption and is very popular in the business world, both the business of food products, pharmaceuticals and cosmetics. For business people, the word halal is not just a religious concept, it is a concept that sees that halal is seen from the perspective of religion alone, but also has a global meaning, namely business opportunities. ${ }^{9}$ Because many companies see the concept of halal as a new tool for marketing and a world trend. A number of worldclass brands have presented products with a halal identity. The market potential also shows significant increase from year to year. ${ }^{10}$

The rise of halal lifestyle in the realm of global trends has led to an increase in the need for equipment and services. This has become a lucrative business opportunity for business people and related industries ${ }^{11}$, to provide the various needs

4 Asep Syarifuddin Hidayat and Mustolih Siradj, "Legal Arguments of Halal Product Guarantee (Argumentasi Hukum Jaminan Produk Halal)," Jurnal Bimas Islam 8, no. 1 (2015): 31-66.

5 Nasrullah Nurdin, “Bisnis Wisata Halal,” Dialog 42, no. 1 (2019): 107-10.

6 Eka Dewi Satriana Hayyun Durrotul Faridah, “Wisata Halal: Perkembangan, Peluang, Dan Tantangan,” Journal of Halal Product and Research (JHPR) 01, no. 02 (2018): 32-43.

7 Eka Dewi Satriana Hayyun Durrotul Faridah.

8 Hidayat and Siradj, "Sertifikasi Halal Dan Sertifikasi Non Halal."

9. Warta Ekspor, Hidup Sehat dengan Produk Halal, Jurnal Kementrian Perdagangan Republik Indonesia, Ditjen PEN/WRT/56/ VII/2015, Edisi Juli 2015, h. 2

10. Toni Bramantoro, Bisnis di Sektor Halal Lifestyle Saat Ini Memiliki Potensi Sangat Besar kata Sapta Nirwandar, tribunnews.com, Sabtu, 17 Februari 2018, http://www.tribunnews.com/bisnis/2018/02/17/bisnis-di-sektor-halal-lifestyle-saat-ini-memiliki- potensi-sangatbesar-kata-sapta-nirwandar?page $=1$.

11 Lady Yulia, "Strategy Strategi Pengembangan Industri Produk Halal," Jurnal Bimas Islam 8, no. 1 (2015): 121-62. 
and equipment referred to to provide the various needs and equipment referred to. $^{12}$

The data regarding how big the need for halal lifestyle is indeed amazing value. Based on data released by the State of the Global Islamic Economic 20142015 explained that, the total world population is currently around 7 billion. and $25 \%$ of the total are Muslim. ${ }^{13}$ Or if it's quantified 1.7 billion. If we take 56 Muslimmajority countries, the Gross Domestic Product (GDP) is estimated at a total of 6.7 trillion dollars. Quite a large number, especially if converted, of course very many in number.

Of that amount, the total Muslim funds spent on halal lifestyle needs ranged from 2 trillion dollars in 2013 and this figure increased 9.5 percent over the previous years, until 2019 the amount of funds is projected to increase reaching 3.7 trillion dollar. As for the details, 1.292 billion dollars in the food and beverage sector, 1,214 billion dollars in the financial sector, 140 billion dollars in the tourism and trevel sector, 266 billion dollars in clothing, 72 billion dollars in pharmaceuticals and medicine, 185 billion dollars in media and recreation, then 46 billion dollars for the cosmetics and cosmetic tools sector. ${ }^{14}$

For Indonesian Muslims, the funds spent on halal lifestyle are no less fantastic. For the food and beverage sector 190.4 billion dollars, for the financial services sector 36 billion dollars, for the tourism and trevel sector 7.5 billion dollars, for clothing 18.8 billion dollars, for pharmaceuticals and medicines 4.88 billion dollars, for media and recreation for 9.37 billion dollars and for cosmetics for 3.44 billion dollars. ${ }^{15}$

This data shows that the halal business in particular in Indonesia has become a very interesting object. How big is this halal business opportunity, but it is all different from the reality when the Muslim community's need for halal products with unbalanced product availability. Citing data from the National Standardization Agency (BSN), halal certification in Indonesia only reaches less than 20 percent. ${ }^{16}$ This is slightly different from the data released by the Directorate General of Islamic Community Guidance, which states that the total percentage of halal certified products from 2011 to 2014 is $26.11 \%$ so that food products, cosmetics, and medicines

12 Hidayat and Siradj, "Sertifikasi Halal Dan Sertifikasi Non Halal."

13 Ratna Pertiwi Tjaja, Menuju Penduduk Tumbuh Seimbang Tahun 2020, Workshop Apresiasi Kebijakan Ketransmigrasian dan Kependudukan di Kantor Menteri Negara Transmigrasi dan Kependudukan, Jakarta 23 November 2000, h. 1

14. Thomson Reuters, State of the Global Islamic Economy 2014-2015, Dubai The Capital of Islamic Economy, Dubai 2014/2015, h. 22

15 .Misbahul Munir, Akselerasi Tren "Halal Lifestyle" indonesiana.tempo.co.id, Kamis 27 Oktober 2016, https://indonesiana.tempo. $\mathrm{co} / \mathrm{read} / 96252 / 2016 / 10 / 27 /$ robjanuar/ akselerasi-tren-halal-lifestyle

16. Arie Lukihardianti, Industri Makanan Bersertifikat Halal Masih Minim di Jabar, Republika, 21 September 2017, http://nasional. republika.co.id/ berita/nasional/daerah/17/ 09/21/owlws1384-industri-makanan-bersertifikat-halal-masih-minim-di-jabar 
that are in circulation and not certified in 2011-2014 of $73.89 \% .{ }^{17}$ Meanwhile, according to the halal certification data published by the Central LPPOM MUI until October 2017, it shows that the number of companies that conduct halal certification is as much as 6055 , with the number of certificates issued as many as 7764 and the products distributed as many as 259984 .

For certification at the provincial level up to 2016 the number of companies carrying out halal certification was 32292, with 33310 certificates issued and 150156 products distributed. ${ }^{18}$ For the West Java region, with a Muslim population of between $85-90 \%$, in the last 5 years, LPPOM-MUI issued 13,136 halal certificates from the total products circulating in Indonesia as many as 155,774 products. While the Food and Drug Supervisory Agency (BPOM) noted so far, the number of registered products reached 175,157 products. However, only about 103,382 products or about 59.01 percent are MUI certified halal. ${ }^{19}$

From this data it shows that although the need for halal products is high but it is still not ideal, it is still far below the standard when viewed from the Muslim population as much as $87 \%$ of the total population of Indonesia. It also shows the complex obstacles in achieving halal certification to fulfill the number of halal products needed by the community.

\section{B. Literatur Review}

\section{Business}

Business is a term to describe all the activities of various institutions from those that produce goods and services necessary for everyday people's life. ${ }^{20}$ In general, business is defined as an activity carried out by humans to obtain income or income or rizki in order to meet the needs and desires of life by managing economic resources effectively and efficiently. The business economic sectors include the agriculture, industrial, service and trade sectors. ${ }^{21}$ More specifically Skinner defines business as the exchange of goods, services, or money that is mutually beneficial or beneficial. As for Straub and Attner's view, business is none other than an organization that carries out the activities of producing and selling goods and services desired by consumers

17 . Dirjen Bimas Islam Kementerian Agama Republik Indonesia, Persentase Produk Yang Beredar Dan Produk Bersertifikat Halal, diakses Kamis, 19 April 2019, http:/ / simbi.kemenag.go.id/halal/assets/ collections/newsletter/files/55642c827e6ac.pdf 18 . LPPOM MUI, Statistik Sertifikasi Halal Indonesia, Data Sertifikasi Halal LPPOM MUI Januari - Oktober 2017, http: / /www.halalmui.org/mui14/index.php/main/go_to_section/59/1368/page/1

19 .https: / jabartoday.com/ekonomi/2016/11/17/1202/25587/baru-59-produk-kantungi- sertifikat-halal

20 Manullang, M. Pengantar Bisnis, Yogyakarta : Gadjah Mada University Press.( 2002) h.8

21 Muslich. Etika Bisnis Islami; Yogyakarta: Ekonisia Fakultas EkonomiUII (2010). h.4 
for profit. ${ }^{22}$ In Islam, business can be understood as a series of business activities in various forms that are not limited to the amount (quantity) of property ownership (goods / services) including profit, but are limited in how they are obtained and utilized (there are halal and haram rules). ${ }^{23}$ The definition above can be explained that Islam requires every Muslim, especially those who have dependents to work. Work is one of the main reasons that allows humans to have property. To enable humans to try to make a living, Allah SWT enlarges the earth and provides various facilities that can be used to seek fortune.

Business and trade are inseparable parts of Islamic teachings. During the time of the Prophet Muhammad was not only involved in trade within the region but also to other countries to establish business relations. In Islamic teachings there are detailed rules for trade, politics, interest, debt, contracts and finance. Islam allows and even encourages its people to do business. ${ }^{24}$

\section{Halal Products}

In this study the description of halal products refers to the Republic of Indonesia Law Number 33 of 2014 concerning the Guarantee of Halal Products. Article 1 states that products are goods and / or services related to food, beverages, medicines, cosmetics, chemical products, biological products, genetically engineered products, and consumer goods that are used, used or utilized by the community. Halal products are products that have been declared halal in accordance with Islamic law.

Halal is a term from Arabic which means permissible, legal, and according to Islamic law or sharia. If it is related to pharmaceutical products, food and beverages, then halal can be interpreted as a pharmaceutical product, food or drink that is allowed to be consumed by a Muslim. ${ }^{25}$ Sharia regulations allow everyone to eat and drink or consume anything, including pharmaceutical products, which is preferred as long as these products are not haram. The following are various rules about the halalness and prohibition of a product: ${ }^{26}$

1. Basically everything is permissible, with a few exceptions that are specifically prohibited.

2. legalizing and forbidding any product is the sole right of Allah SWT.

22 Yusanto, Muhammad Ismail dan Muhammad Karebet Widjajakusuma. Menggagas Bisnis Islami, Jakarta: Gema Insani Press(2002) h.14

23 Ibid.h.18

24 Muhammad. 2004. Etika Bisnis Islam, Yogyakarta : UPP AMP YKPN. h.67

25 Abdul Rohman, Pengembangan dan Analisis Produk Halal, (Yogyakarta: Pustaka Pelajar, 2012), hal. 1

26 Ibid, hal. 2-3 
3. To forbid what is halal and justify what is haram is similar to shirk (associate Allah SWT).

4. The fundamental reason for the prohibition of anything is badness and danger.

5. in the halal there is something that can prevent the haram. Allah SWT only forbids everything that is needed by replacing it with something better.

6. Anything that brings to non-halal products is not allowed.

7. having a strategy on non-halal products is not allowed.

8. Good intentions cannot justify what is haram

9. Keeping away from things or products that are doubtful (doubtful) is recommended for fear of falling on non-halal products.

10. There is no sorting of a non-halal product.

Meanwhile, according to the JPH Law, halal products are products that have been declared halal as appropriate Islamic law and guarantee of halal products are legal certainty of the halalness of a product as evidenced by a halal certificate. Meanwhile, in the Al-Qurán, it is emphasized that food and drinks that are forbidden are carcasses, blood, pork, and meat of animals slaughtered by mentioning names other than Allah SWT, as well as Khamr or intoxicating drinks. ${ }^{27}$ Actually what is forbidden by Allah SWT to eat is the amount the least. The rest, what is on the face of this earth is basically lawful, except what is explicitly prohibited in the Al-Qur'an and Hadith.

So in general, it can be interpreted that a halal product is a product that meets the requirements of halalness in accordance with Islamic law, namely: ${ }^{28}$

1. does not contain pork and ingredients derived from pork.

2. does not contain prohibited materials such as materials derived from human organs, blood, impurities, and so on.

3. all materials derived from halal animals slaughtered according to the procedures of Islamic law.

4. All storage, sales, processing and transportation places are prohibited used for pigs. If ever used for pork or other non-halal goods first, it must be cleaned in a manner regulated by Islamic law.

27 "Kewajiban Mengkonsumsi Makanan Halal”, (http://www.halalmui.org/newMUI/index.php/main/go_to_ section/14/39/page/1, 20 Maret 2019).

28 Ahmad Yusro Arifin, “Urgensi Sertifikasi Halal Bagi Upaya Perlindungan Konsumen di Indonesia”, Skripsi, Fakultas Hukum, Universitas Islam Insonesia, 2011, h. 19-20 
5. all foods that do not contain khamr. However, technological developments have created various processed products whose halalness is doubtful. Many of these haram materials are used as raw materials, additives, or auxiliary materials in various processed products, because they are considered more economical. As a result, the halalness and prohibition of a product are often not clear because they are mixed up with ingredients of questionable halalness. This causes a variety of processed products to become distasteful or doubtful and their halal status is unclear.

Based on the foregoing, the MUI Fatwa Commission concluded that all products Processed is basically syubhat. Therefore, it is necessary to study and study before determining the halal or haram status of a product. This is done to protect Muslims from consuming a product.

\section{Economic Impact Of Covid-19 On The Economy And Business Of The Halal Industry}

In the midst of the growing sharia economy as well as the halal product business, the COVID-19 pandemic has had a significant economic impact. ${ }^{29}$ Market players experienced a decline in production due to disruption of the supply chain for raw materials as a result of the PSBB (Large-Scale Social Restriction) policy. Likewise, with the closure of malls, restaurants, public spaces, and the prohibition of mass gatherings, there has been a decline in demand for goods and services which in the end also resulted in many businesses having to go out of business. As a result, several companies lay off their employees. It is estimated that due to the COVID19 pandemic there will be around 4 million unemployed. So there is a decrease in production and consumption, which will result in a decrease in Indonesia's GDP. Some of the sectors that have been badly affected by COVID-19 are MSMEs, tourism, transportation, garments, manufacturing. In the tourism sector, the number of tourists has decreased since January 2020 by $-30.42 \%$ due to the spread of the Covid19 outbreak. The hotel industry has also experienced a decline including halal tourism. 1,266 hotels in 31 provinces in Indonesia have closed due to the COVID19 pandemic (BPP PHRI 2020). Likewise, recreational vehicles have decreased by $90 \%$, industrial events decreased by $84 \%$, and cancellations of travel agents have reached $94 \%$ (Kepemparekraf, 2020). The Muslim fashion industry also experienced a sales decline of up to $30 \%$ (detik.com April 2020). ${ }^{30}$ In the commercial financial sector, the Islamic banking sector which controls the largest portion of Islamic

29 Shinta Rahmadia et al., "Dampak Covid-19 Terhadap Ekonomi,” 2020.

30 Hidayah, "Covid-19." 
finance, experienced an impact. As a financial intermediary institution, ${ }^{31}$ on the side of third party funds, banks experienced rush money, while on the financing side, banks experienced an increase in NPF (Non-performing Finance). Islamic financial institutions experience increased risks, both operational risk, financing risk, market risk, and so on. Likewise in the capital market, shares on the stock exchange market, including Islamic stocks, experienced a correction of 20-30 percent. As a result, many investors released their shares and there was a large capital flow because it increased the risk of investment in Indonesia. Likewise, the rupiah exchange rate against the dollar weakened. The distribution of Islamic Fintech financing is delayed by $80 \%$ (Ammana Fintech 2020). In the non-bank financial sector, many customers are unable to pay their financing installments.

\section{Research Method}

This research uses the library research method by using literature originating from journals, books, and proceeding conferences. This research uses descriptive qualitative method by using documentation data in the form of books, reports from official institutions such as BPS, OJK, BI, Ministry of Trade, Kemenpan and scientific journals. A literature study aims to introduce theories(Creswell, 2014), extract information ${ }^{32}$ (Johari et al., 2014). The data obtained through a literature study is done by collecting and studying literature from various sources, especially from journals ${ }^{33}$, books, and research results related to this research, This study aims to examine the halal business opportunities and challenges in Indonesia pasca pandemi COVID-19 and describing the situation ${ }^{34}$

\section{E. Result and Discussion}

\section{Potential of Halal Business in Indonesia}

Indonesia is a country with the largest Muslim population in the world. This situation makes Indonesia have a huge potential in the halal product development industry in the world. Because of the world's largest Muslim population, Indonesia's main market is its own country.

31 Jurnal Ekonomi et al., "Dampak Pandemi Covid-19 Terhadap Manajemen Industri Perbankan Syariah: Analisis Komparatif," n.d., 1-10.

32 Efri Syamsul Bahri and Zainal Arif, "Policy Analysis of Zakat Profession in Indonesia" 2011, no. 29059 (2020): 29059-67.

33 Zainal Arif, "Bisnis Produk Halal Antara Peluang Dan Tantangan, Problematika Dan Solusinya” 20, no. 1 (2020): 274-94, https: / / doi.org/https: / / doi.org/10.30603/au.v20i1.1170.

34 Arif. 
If you look at some data regarding the potential of halal lifestyle on a global level up to Indonesia, it will appear that the opportunity for the development of the halal lifestyle industry is huge. All Muslims living on this earth need everything that is lawful. So it is natural that currently several countries in various parts of the world are starting to vigorously compete for the enormous potential of the halal lifestyle industry..

In pharmaceutical products, based on geographical location, Indonesia is one of the countries with the fastest growing pharmaceutical market in the world. According to GM Quintilies IMS Indonesia, the Indonesian pharmaceutical market grows an average of 20.6\% per year, from 2011-2016 and there are currently around 239 pharmaceutical companies operating in Indonesia ${ }^{35}$. Most of the pharmaceutical industry is in West Java (39\%) or (94), East Java (20\%) as much as 47 (47), and the Jakarta DKl $(15 \%)$ or as much as $(37),{ }^{36}$. The sector is dominated by the basic chemical industry, chemical goods, and pharmaceuticals worth Rp 12.9 trillion. For the realization of foreign investment (PMA), the industry is included in the top five investments with a value of US $\$ 700$ million. ${ }^{37}$ In addition, the pharmaceutical sector contributes around $27 \%$ of ASEAN's total pharmaceutical market share. ${ }^{38}$ Prescription drugs dominate the national market in Indonesia, around 59\% of the national pharmaceutical market and the remaining $41 \%$ are over the counter (OTC) drugs. This is in line with increasing public awareness of the importance of health. Prescription drugs consist of patent medicines (30\%) and generics $(70 \%)$, where generics are divided into branded generic drugs and ordinary generic drugs (OGB). The OGB market is still relatively small (around $8.3 \%$ of the total prescription drug market), so the potential for OGB growth will increase in line with BPJS implementation. This shows the huge market potential for pharmaceutical companies in Indonesia. ${ }^{39}$

35 Asep Budiman, Pertumbuhan Pasar Farmasi Indonesia Tercepat di Asia, Pikiran Rakyat, 16 Maret 2017, http: / www. pikiran rakyat.com/ekonomi/2017/03/16/pertumbuhan-pasar-farmasi-indonesia-tercepat-di-asia-396400

36 .Asep Budiman, Pertumbuhan Pasar Farmasi Indonesia Tercepat di Asia, Pikiran Rakyat, 16 Maret 2017, http://www. pikiran-rakyat.com/ekonomi/2017/03/16/pertumbuhan-pasar-farmasi-indonesia-tercepat-di-asia-396400

37 Anastasia Arvirianty, Industri Farmasi Semakin Sehat, Media Indonesia, Jumat, 17 Maret 2017, http://www. mediaindonesia.com/read/detail/96887-industri-farmasi-semakin-sehat

38. Asep Budiman, Pertumbuhan Pasar Farmasi Indonesia Tercepat di Asia, Pikiran Rakyat, 16 Maret 2017, http: / /www. pikiran-rakyat.com/ekonomi / 2017/03/16/pertumbuhan-pasar-farmasi- indonesia-tercepat-di-asia-396400

39 Saribua Siahaan, Peluang Investasi di Sektor Farmasi Indonesia, Indonesia Investment Promotion Center (IIPC) Tokyo, h. 1 


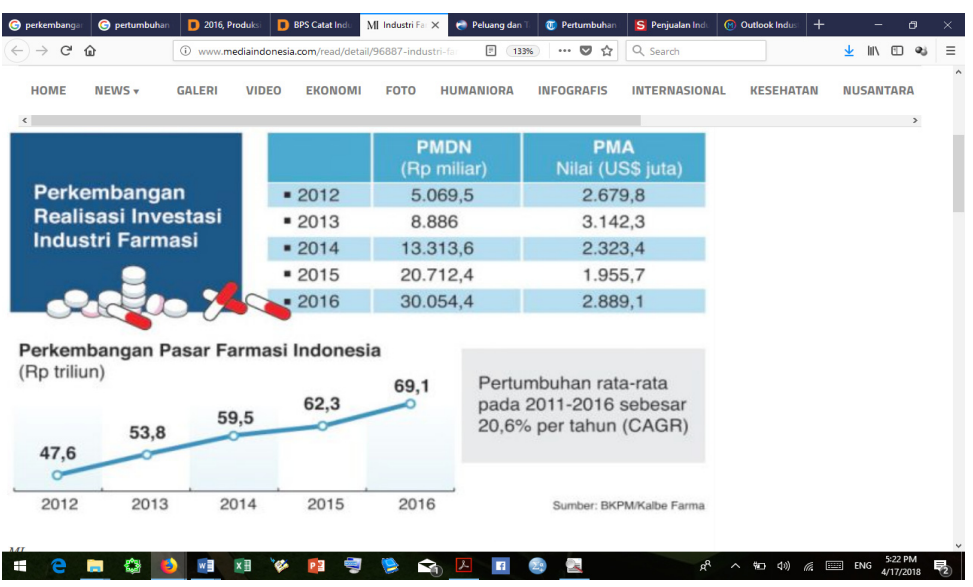

Then for food and beverage products, Indonesia is known for a variety of many specialties. Each region has its own special food. And that is also a very large number. Some of the famous ones, namely Pempek Palembang, Nasi Padang, Gudeg Jogja. Those are some of the famous ones. And there are many others. All the food remains is polished and adjusted to the tongue of foreign visitors. And it must be halal, of course. ${ }^{40}$ If you can polish typical food well, this will be one of the greatest opportunities, namely the food business. In addition, it will also raise the name of Indonesian culinary in the world class. ${ }^{41}$

Based on the records of the Global Islamic Economy Report 2016/2017 ${ }^{42}$, The global Muslim population spending on products and services in the halal economic sector reached more than USD 1.9 trillion in 2015. At the same time, the assets of the Islamic financial sector are estimated at USD 2 trillion, followed by the food and beverage sector at USD 1.2 trillion, clothing (USD 243 billion), media and recreation (USD 189 billion), travel (USD 151 billion and medicine and cosmetics (USD 133 billion). ${ }^{43}$ ndonesia ranks first as the largest consumer of halal products in the food and beverage sector, with total expenditure of the food and beverage sector amounting to USD 155 billion.

40 Muchtar Ali, "Konsep Makanan Halal Dalam Tinjauan Syariah Dan Tanggung Jawab Produk Atas Produsen Industri Halal," AHKAM : Jurnal Ilmu Syariah 16, no. 2 (2016): 291-306, https:/ / doi.org/10.15408/ajis.v16i2.4459.

41 .Misbahul Munir, Akselerasi Tren "Halal Lifestyle" indonesiana.tempo.co.id, Kamis 27 Oktober 2016, https:/ /indonesiana.tempo. $\mathrm{co} / \mathrm{read} / 96252 / 2016 / 10 / 27 /$ robjanuar/akselerasi-tren-halal-lifestyle

42. Thomson Reuters, State of the Global Islamic Economy Report 2017/18, Dubai The Capital of Islamic Economy, Dubai 2017/2018, h. 44

43 .Dwi Rahmayani, Peluang Emas Membidik Bisnis Makanan Halal Global, http://www.coreindonesia.org, Kamis, 5 April 2018, http://www.coreindonesia.org/ view/241/peluang-emas-membidik-bisnis-makanan-halal-global.html 


\section{Indonesian Halal Business Opportunities}

The halal food product business in Indonesia is closely related to the growth of the Muslim population. As a predominantly Muslim country, Indonesia has the opportunity to become the center of the largest halal economy in the world. ${ }^{44}$

Publications conducted by the Indonesian Central Bureau of Statistics state that Indonesia's population in 2010 reached 237.6 million, with a Muslim population of $207,176,162$, or $87.18 \%$ of the total population of Indonesia. In 2017 , Indonesia's population reached 261.9 million. ${ }^{45}$ This figure shows a very rapid growth when compared to $2010 .{ }^{46}$ Thus, in a period of 7 years, the average growth of Indonesia's Muslim population in the 2010-2017 period reached $1.27 \%-1.46 \%$. per year. The rapid growth of the Muslim population has linearly affected the growth in demand for halal products. This can be seen from the demand for halal products. It is natural for the number of followers of Islam to make the government issue Law no. 33 of 2014 concerning Halal Product Guarantee in order to protect the interests of consumers who have the right to use products that comply with Islamic law, both in terms of materials, manufacturing processes and wrapping stages. ${ }^{47}$

Indonesia is a country that has a comparative advantage as an agricultural and maritime country which has a huge economic potential to be developed into valueadded activities. Halal products have an average growth rate of seven percent per year, as well as the growing awareness of Muslim consumers towards halal products and the increasing number of Muslim population which reaches 1.8 billion people from 5.5 billion people in the world. With the aforementioned developments, halal producers and business players have plans for international market expansion, including for the expansion of the Indonesian halal product market. ${ }^{48}$

Data reported by the Central Statistics Agency (BPS) also explains that household consumption is still the biggest driver of economic growth with a percentage of 55.68 percent in the third quarter of 2017. The need for Indonesian families for household products is very high so as to meet these needs and for the

44 Arin Fithriana and Rendy Putra Kusuma, "Implementasi Kebijakan Pangan Halal Indonesia: Keunggulan Kompetitif Dalam Tren Pangan Halal Di Asia Tenggara,” Global Insight Journal 03, no. 02 (2018): 1-18.

45 . Badan Pusat Statistik, Sensus Penduduk 2010; Penduduk Menurut Wilayah dan Agama yang Dianut, www.bps.go.id, https:// sp2010.bps.go.id/index.php/site/tabel?tid=321.

46 Faqiatul Mariya Waharini and Anissa Hakim Purwantini, "Model Pengembangan Industri Halal Food Di Indonesia,” Muqtasid: Jurnal Ekonomi Dan Perbankan Syariah 9, no. 1 (2018): 1, https: / / doi.org/10.18326/muqtasid.v9i1.1-13.

47 Panji Adam Agus, "Kedudukan Sertifikasi Halal Dalam Sistem Hukum Nasional Sebagai Upaya Perlindungan Konsumen Dalam Hukum Islam,” Amwaluna: Jurnal Ekonomi Dan Keuangan Syariah 1, no. 1 (2017): 150-65, https:// doi.org/10.29313/amwaluna.v1i1.2172.

48 . Dwi Purnomo, Strategi Pengembangan Agroindustri Halal Dalam Mengantisipasi Bisnis Halal Global, Bogor, Disertasi Institut Pertanian Bogor, 2011, h. vii 
sake of To ensure the peace of Muslim consumers, halal and safe products are needed for Indonesian families. ${ }^{49}$

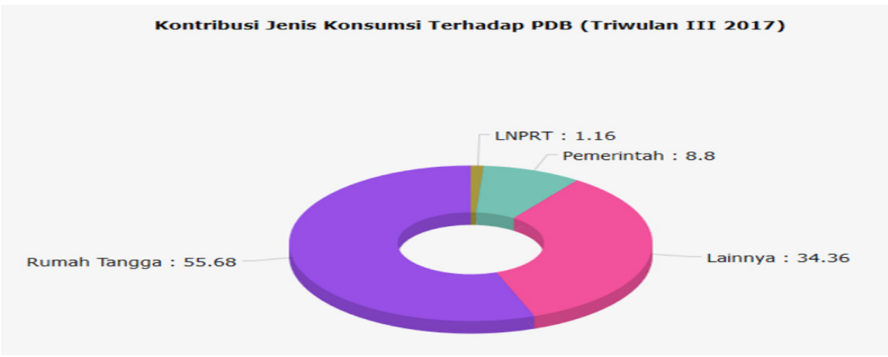

BPS data; Contribution of Consumption Type to GDP (Quarter III 2017)

In addition, Indonesia is a country where Halal Food Consumption is ranked 1 in the world ${ }^{50}$. Based on the records of the Global Islamic Economy Report 2016/2017, the global Muslim population spending on products and services in the halal economic sector reached more than USD 1.9 trillion in 2015. At the same time, the assets of the Islamic financial sector are estimated at USD 2 trillion, followed by the food sector. and beverages amounting to USD 1.2 trillion, the clothing sector (USD 243 billion), media and recreation (USD 189 billion), travel (USD 151 billion and medicines and cosmetics (USD 133 billion). ${ }^{51}$ Indonesia ranks first as the largest consumer of halal products in the food and beverage sector, with total sector expenditure of USD155 billion. ${ }^{52}$

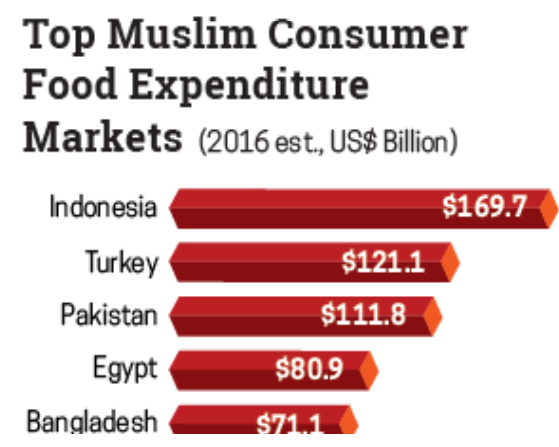

Data State of the Global Islamic Economy Report 2017/2018

49 . Lembaga Badan Pusat Statistik (BPS), Mengapa Konsumsi Rumah Tangga Penting bagi Perekonomian, Kata Data News and Researcs, databoks.katadata.co.id, Jum"at, 8 Desember 2017, https://databoks.katadata.co.id/datapublish/2017/12/08/mengapa-konsumsi-rumahtangga-penting-bagi-perekonomian.

50. Thomson Reuters, State of the Global Islamic Economy Report 2017/18, Dubai The Capital of Islamic Economy, Dubai 2017/2018, h. 44.

51 .Dwi Rahmayani, Peluang Emas Membidik Bisnis Makanan Halal Global, http:/ /www.coreindonesia.org, 30 May 2017, http:/ / www. coreindonesia.org/view/241/ peluang-emas-membidik-bisnis-makanan-halal-global.html

52 .Dwi Rahmayani, Peluang Emas Membidik Bisnis Makanan Halal Global, http:/ / www.coreindonesia.org, 30 May 2017, http:/ / www. coreindonesia.org/view/241/ peluang-emas-membidik-bisnis-makanan-halal-global.html 
As a country with a majority Muslim population, Indonesia has an interest in increasing non-oil and gas exports ${ }^{53}$. For this reason, Indonesia has prepared a legal instrument through Law No. 33 of 2014 concerning Halal Product Guarantee which essentially regulates the halalness of a product ${ }^{54}$, to protect the interests of domestic consumers towards imported goods that have been tested for their halalness and to secure export of commodity products so that they can be accepted, especially to Middle Eastern and OIC countries. ${ }^{55}$

Business competition in competing for the global halal product market in ASEAN neighboring countries including Indonesia and Malaysia is difficult to avoid..$^{56}$ Halal products in the world control about $11 \%$ of all products and services. With this huge potential, the synergy between Muslim countries such as Malaysia and Indonesia is important. The big potential in the halal industry is food and beverage, pharmacy and beauty. ${ }^{57}$

In facing the MEA, ${ }^{58}$ Indonesian halal products have a great opportunity, to be able to compete with other countries. Business actors, both Indonesian producers and exporters, who have pocketed a halal certificate, their products will be more easily accepted by consumers of halal products in other countries just by looking at the halal label listed on their products. For example, if a consumer of halal products in another country wants to buy canned food and there are two choices of similar canned food, then that consumer will tend to choose a product that has a halal label because they feel they are guaranteed that the product they are going to consume is really halal and good. For animal meat, for example, slaughtering is done by cutting the neck of the animal with the aim of taking the meat. Islamic slaughter is defined as slaughtering according to Islamic law. Meat produced from Islamic slaughter produces meat that is rich in taste, soft, safe and hygienic. This is what makes other Muslim consumers interested in products with halal guarantees. ${ }^{59}$

53. Warta Ekspor, Jurnal Kementrian Perdagangan Republik Indonesia, Ditjen PEN/WRT/56/VII/2015, Edisi Juli 2015, h. 13

54 Hidayat and Siradj, "Legal Arguments of Halal Product Guarantee (Argumentasi Hukum Jaminan Produk Halal)."

55 . Handoyo, Potensi Besar Dari Bisnis Halal, Jakarta, nasional.kontan.co.id, News Data Financial Tool, Senin, 01 Agustus 2016, https://nasional.kontan.co.id/news/ potensi-besar-dari-bisnis-halal

56 Fithriana and Kusuma, "Implementasi Kebijakan Pangan Halal Indonesia: Keunggulan Kompetitif Dalam Tren Pangan Halal Di Asia Tenggara."

57 Handoyo, Potensi Besar Dari Bisnis Halal, Jakarta, nasional.kontan.co.id, News Data Financial Tool, Senin, 01 Agustus 2016, https://nasional.kontan.co.id/news/ potensi-besar-dari-bisnis-halal

58 Zainal Arif, “Optimalisasi Peluang Dan Tantangan Ekonomi Islam Dalam Menghadapi Masyarakat Ekonomi Asean,” Al Maal: Journal of Islamic Economics and Banking 1, no. 1 (2019): 89, https: / doi.org/10.31000/almaal.v1i1.1817.

59. Warta Ekspor, Jurnal Kementrian Perdagangan Republik Indonesia, Ditjen PEN/WRT/56/VII/2015, Edisi Juli 2015, h. 6 


\section{Challenges and Barriers to Business of Halal Products in Indonesia}

As a country with the largest Muslim population in the world, Indonesia still ignores the potential of the domestic halal business. So that in the long term, Indonesia could be threatened to become the largest halal market destination in the world, not as the world's main actor and producer of halal products. This is because Indonesia does not have strategic steps to increase its competitiveness to be able to compete at the international level. ${ }^{60}$

Indonesian business actors have not considered the halal industry as an important business opportunity. This is due to the fundamental attitude of business actors who do not have a culture of Awareness towards halal products, even though in fact the halal industry is now a global trend in the world. This occurs in the attitude of business actors who tend to be still unaware of the importance of halal products and their lack of orientation to seize the world halal industry market.

In addition, many business actors do not care about consumer rights, but are more concerned with pursuing the highest profit. Second, in most developing countries including Indonesia, business actors are more protected by the government than consumers because business actors are considered to have great services in supporting the country's economy. Third, in a socio-political system where legal certainty does not work, business actors will easily buy power to protect their interests against consumer demands. Fourth, in various ways consumers are on the weak side when compared to the position of producers. ${ }^{61}$

In terms of pharmaceutical products, Indonesia is one of the fastest growing pharmaceutical markets in Asia. However, ironically, Indonesia has a dependency on imported medicinal ingredients from non-Muslim countries, which are imported from China, Canada, the United States, India, Japan, and several countries in Europe and others. The amount of imported medicinal ingredients from these countries is around $95 \%$ of the total materials needed for the production of synthetic drugs ${ }^{62}$. As it is known, the halal ingredients of these imported medicines are questionable. This factor is what makes drug certification in Indonesia still in the range of below $1 \%$. This is in line with the government's lack of attention in providing facilities

60 . Dwi Purnomo, Strategi Pengembangan Agroindustri Halal Dalam Mengantisipasi Bisnis Halal Global, (Bogor: Disertasi Institut Pertanian Bogor, 2011), h. vii.

61. M. Ah Mansyur, Penegakan Hukum tentang Tanggung Gugat Produsen dalam Perwujudan Perlindungan Konsumen Naskah Disertasi Program Doktor Ilmu Hukumm Universitas Diponegoro, (Semarang: 2004), h. 228-229

62. Saribua Siahaan (Director of IIPC), Peluang Investasi di Sektor Farmasi Indonesia, Profile of Indonesia Investment Promotion Centre (IIPC) in Tokyo (representative office of Indonesia Investment Coordinating Board/BKPM), Tokyo Japan, http://www.gmp-platform.com/files/ user/industri farmasi indonesia.pdf 
for how the halal industry grows and develops. Even worse, the ministry of health firmly rejects halal certification of drugs.

Even though the JPH Law was enacted in 2014, until now it has not been effective. Even though the birth of the JPH Law is expected to be the umbrella provisions for all halal regulations. This then also affects the lagging behind the Indonesian halal industry compared to other countries. The process of changing from the Draft Bill to the Halal Product Guarantee Law (JPH) also creates obstacles. Some of these obstacles include: First, there is an assumption that the Product Guarantee Bill is a draft law that has no national insight, is not pluralist and is discriminatory. This is because he is more in favor of the interests of Muslims who are the majority in Indonesia; Second, the Bill on Halal Product Guarantee is considered legally flawed because the discussion conducted by Commission VIII DPR RI did not involve all parties maximally and was not aspirational. Third, the discussion of the Draft Bill on Halal Product Guarantee, there was a tug of war between the Ministry of Religion and MUI. So far, with the mandate given by the Ministry of Religion, through LPPOM-MUI it is the only institution that has the authority to issue halal certificates.. ${ }^{63}$ "It was agreed that a food and beverage product in circulation could be declared halal only on the basis of a Fatwa from the Indonesian Ulema Council, after going through a series of audits at the producer location and careful laboratory testing." ${ }^{64}$ MUI wants the Halal Product Guarantee Bill to establish MUI as the sole authority. However, the government wishes otherwise. Through the Ministry of Religion, the MUI authority is trimmed only to become a halal fatwa body, while the halal certificate is issued by the Ministry of Religion. That is why, MUI hopes that this institution has been established so far.

The low public response to halal certified products is also a challenge. Muslim scholars are well aware of this, as emphasized by Sukoso in the National Symposium Seminar on Indonesian Halal Products. He explained the importance of public awareness to open insights in studying legalized products, especially products that are consumed, such as food and beverages and medicines. "We know and are well aware that Indonesia is one of the countries with the largest Muslim population in the world. As many as 82 percent of Indonesians embrace Islam. However, it is very ironic when considering the current condition of the halal industry is no longer conducive. Meanwhile, other nations such as Japan. , Thailand and South Korea,

63. Mashudi, Kontruksi Hukum dan Respons Masyarakat Terhadap Sertifikasi Produk Halal, Seri Disertasi, (Semarang: Pustaka Pelajar, LP2M UIN Walisongo, 2015), h. 415.

64 Piagam Kerjasama Departemen Kesehatan, Departemen Agama dan Majelis Ulama Indonesia tentang Pelaksanaan Pencantuman Label Halal pada Makanan tanggal 21 Juni 1999 
whose majority are non-Muslim, are actually concerned about the halal product industry." 65

Various public responses to halal product certification include several factors: First, the factor of religious moral beliefs. Halal discourse is a religious doctrine, based on revelation and in the form of normative texts. Therefore, every Muslim believes in this text and applies it in his daily life to devote himself to Allah. However, not all Muslims are able to capture and apply the text to become a living law, so a change in human attitude is needed. This is where the importance of the double movement theory. This theory reveals that all religious rules originate from revelations that were sent down to mankind to be used for the benefit of their lives. Then, the process of human life which is based on the noble values of the revelation becomes the basis for devoting oneself to Allah SWT. ${ }^{66}$

Second, economic considerations. It is this consideration factor that often dominates producers and consumers in influencing changes in attitudes towards halal product certification. According to Kelman, there are three social processes that play a role in the process of changing attitudes, namely willingness (compliance), identification (identification), and internalization (internalization). ${ }^{67}$

If producers and consumers are willing to change their attitudes, from the behavior of producing and buying origin, then the quality of the food produced and consumed will have an impact on food safety. Likewise in the process of identification and internalization of food and other products. Meanwhile, a person's behavior towards law (the Behawior of Law) according to Donald Black should include stratification, morphology, culture, organization, and social control. ${ }^{68}$

Third, the legal factor. Business actors must always be based on the provisions of laws and regulations in carrying out their business units and have good faith in the legal regulatory framework. ${ }^{69} \mathrm{~A}$ number of reasons are the cause of the emergence of social inequality and have juridical implications for the next process, such as using raw materials that are haram according to religion, using addictive substances without permitted procedures, and others. To that end, the principles of economic law that deserve attention include "the principle of balance of interests,

65. Zenefale, Trend Global Produk Halal Menjadi Gaya Hidup Negara-Negara Non Muslim, Artikel 13 October 2015, https://prasetya. ub.ac.id/berita/Trend-Global-Produk-Halal-Menjadi-Gaya-Hidup-Negara-Negara-Non-Muslim-17511-id.pdf.

66. Fazlur Rahman, Islam dan Modernity: Transformation of an Intelectual Tradition, (Chicago \& London: The Uviversity of Chicago Press, 1984), h. 9

67. Saifuddin Azhar, Sikap manusia; Teori dan Pengukurannya, (Yogyakarta: Pustaka pelajar, 2009), h. 55

68. Donald Black, The Behavior of Law, (New York: Academic Press, 1976), h. 13

69. Gede A.B Wiranata, Etika, Bisnis dan Hukum Bisnis, (Bandar Lampung: Universitas Lampung, 2010), H. 63 
the principle of openness and responsibility, the principle of public supervision, and the principle of state interference.

Fourth, cultural factors. In general, the behavior of each consumer in buying any product has a different attitude. The causes for these different attitudes are cultural factors, such as: 1) culture will affect the structure of consumption; 2) culture will influence how individuals make decisions; 3 ) culture is the main variable in the creation and communication of meaning in products. The strategy of understanding the culture is very important because it will determine the next consumer action.

The consumerist culture and hedonic attitudes as seen recently, affect the attitudes of most people. The consideration regarding halal-haram-including halal food- has decreased. For some people, buying in large quantities is a sign of prosperity in itself that many people are interested in. The term "like shopping" has turned into a shopping freak, which is a buying process that is not based on considerations of need and availability of money. As a result, halal products are often not a priority for consideration, including for consumers themselves.

Fifth, geographical factors. The results of this study prove that the geographic difference has implications for significant differences in purchasing food products, medicines and cosmetics between urban and rural communities. Likewise, there are quite striking patterns and differences in the culture of consumerism and most of their patterns of life, between coastal communities and mountainous communities.

According to Russell, the influence factors above show that the characteristics of the consumer's situation also have the potential to influence their behavior. The following are some of the characteristics of the situation: 1) The physical environment (the real nature of which is the consumer's situation) which includes geographic location. 2) Social environment (presence or absence of other people) in the situation concerned. 3) Time, the temporary nature of a particular moment of situation when the behavior occurs. 4) Specific tasks, goals or objectives that consumers have in a situation. 5) The antecedent state (temporary mood).

\section{Optimization and Business Solutions for Halal Products in Indonesia}

If we already know that Indonesia has a lot of potential that can be sold related to the trend of the halal lifestyle at the global level, then the next question is how to optimize this potential. So that this potential can be accelerated by the growth of the halal lifestyle in the global realm. ${ }^{70}$ Because don't let this big field full of treasures called the halal lifestyle be seized by other countries. Our resources are very abundant, both human resources (HR) and natural resources. So we must be

70 Arif, “Optimalisasi Peluang Dan Tantangan Ekonomi Islam Dalam Menghadapi Masyarakat Ekonomi Asean.” 
able to manage these resources optimally. So that later we can meet market needs for a halal lifestyle, both domestic and foreign markets.

Making Indonesia the center of the world's halal industry is not something that is impossible. Even Indonesia is very likely to get it. ${ }^{71}$ It remains how we manage it, can we manage properly and correctly so that Indonesia as the center of the halal lifestyle industry is truly realized, not just a discourse. ${ }^{72}$ If that can be realized, it will be easy for us to attract Muslim billionaires from the rich Middle East to come to Indonesia. This will be an income for state finances and also for halal lifestyle stakeholders in Indonesia. ${ }^{73}$

In its development, several strategies are needed as an effort to accelerate the optimization of the halal lifestyle potential that Indonesia has, including; First, the role and intervention of the government. The necessities of life which include food and health are the basic needs of human needs and are the livelihood of many people. Halal certificate is a form of state guarantee for its people, so as to minimize unrest. Unrest in the fields of food, medicine, cosmetics, tools for use that occur in society can tarnish economic and political stability. Therefore, the state has an interest in maintaining national stability. ${ }^{74}$ Neglect of the fulfillment of basic needs will have an impact on instability in society. Therefore, the state must be present to provide guarantees, not only for the availability of food, medicine and cosmetics but also the halalness of these products as the implementation of the 1945 Constitution which mandates that every citizen is guaranteed independence from the state to embrace their respective religions. and worship according to their religion and belief. ${ }^{75}$ The state, in this case the government, has authorities in a political system and is responsible for solving community problems in order to create national benefit and stability by formulating policies that bind the people. Public policies related to food, for example, are stated in Government Regulations, Ministerial Regulations and Laws providing guidelines for implementing halal certification to guarantee halal products in the community.

Second, Law No. 33/2014 on Halal Product Guarantee (JPH Law) must be a tool that can engineer change as stated by Roscoe Pound: "Law is a social engineering

71 istikomah, "Peluang Dan Tantangan Implementasi Uu Jph (Studi Analisis Atas Uu No. 33 Tentang Jaminan Produk Halal)," AtTasharruf; Jurnal Kajian Ekonomi Dan Bisnis Syariah 1, no. 1 (2019): 18-28.

72 an Ras Try Astuti And Rukiah, "Bisnis Halal Dalam Perspektif Etika Islam: Kajian Teoritis," AL MA' ARIEF: Jurnal Pendidikan Sosial Dan Budaya 1, no. 2 (2019): 142-56.

73 Yulia, "Strategy Strategi Pengembangan Industri Produk Halal."

74. Mutimmatul Faidah, Sertifikasi Halal Di Indonesia Dari Civil Society Menuju Relasi Kuasa Antara Negara Dan Agama, VOLUME 11 , NOMOR 2, MARET 2017, ISLAMICA, h. 468 https:// doi.org/10.15642/islamica.2017.11.2_

75 . Pasal 29 UUD 1945, Materi Amandemen Pasal 29 UUD 1945 Bakal Diwarnai Perdebatan, hukumonline.com, Senin, 07 August 2000, http://www.hukumonline.com/ berita/ baca/ hol310/materi-amandemen-pasal-29-uud-1945-bakal--diwarnai-perdebatan. 
tool" that the law is expected to be able to become an agent of social change. This is where the government and society are demanded how the implementation of the JPH Law which must be equipped with various devices can reach the digital market into something that is halal with a system that is of course based on sharia. If that happens, the Indonesian market, which is so large and potential, will have two roles. First, as an industrial market that is consistent in the creation and acceptance of halal-based products, so automatically products that do not have halal certification cannot enter Indonesia. Thus, the JPH Law can provide protection for domestic industries from non-halal foreign products. Second, Indonesia is quickly motivated to emerge as a halal industrial country in the fields of food, fashion, finance and tourism that are considered by the world.

Third, it is necessary to develop human resources and industry. The actors who are the driving force in the halal lifestyle sector also need to be developed. Mainly for human resources as the implementer and field technician. If human resources are well developed, others will follow suit. Then also industrial development. Industrial development is carried out after the development of human resources. ${ }^{76}$ There has been an imbalance related to human resources in the industry, whether related to food, pharmaceutical, cosmetic and other products. Many human resources are equipped with skills in food technology, pharmacology, and others, but are not equipped with a correct understanding of understanding halal-haram. Or vice versa, understand and are good at halal-haram but not accompanied by expertise in science and technology, both food, pharmacy and others. As a result, there is a disconnection and a lack of understanding between the two. Thus, it requires experts who are truly qualified and master in the field of science and a strong understanding of religion, so that efforts to realize a halal lifestyle can be achieved properly, because otherwise we will always lose to other countries and we will always be productive consumers. , even lagging behind non-Muslim countries.

Fourth, making halal certification a part of excellent service. Providing the best service to consumers is part of a business strategy that must be prioritized so as not to lose customers. Ignoring the best of services will be the biggest disaster for the business world. If customers are disappointed with the product offered because the product is of doubtful halalness, they will leave it forever. As is the case with Viostin DS and Enzyplex products, which recently tested positive for pig DNA. For Muslim consumers, halal products are a top priority. Then they will choose a product that guarantees its halalness with guaranteed certification. Therefore for producers

76 .Misbahul Munir, Akselerasi Tren "Halal Lifestyle" indonesiana.tempo.co.id, Kamis 27 Oktober 2016, https: / indonesiana.tempo. $\mathrm{co} / \mathrm{read} / 96252 / 2016 / 10 / 27 /$ robjanuar/ akselerasi-tren-halal-lifestyle 
and entrepreneurs providing halal products is part of excellent service, to pamper Muslim consumers so that they get comfort, security, peace and satisfaction. With the satisfaction of consumers, halal certified products will be sold.

To encourage the acceleration of the halal lifestyle trend in Indonesia, support from all parties is needed, so that in the future Indonesia can truly become the center for the development of the world's halal lifestyle industry. There needs to be good cooperation from various parties with an interest in the development of the halal lifestyle, such as the government as the state policy maker and the general public as actors as well as objects in the development of the halal lifestyle industry. Indonesia's opportunities are huge, the accelerated growth of the halal lifestyle trend is expected to be the answer to this magnitude. ${ }^{77}$

\section{F. Conclusion}

The COVID-19 pandemic has had a huge economic impact including the Islamic economy and finance sector, which was marked by a decrease in demand and supply of goods and services in the Islamic financial industry and halal business. Even though there has been a decline in several sectors such as commercial finance and halal business such as tourism, transportation, garments, and MSMEs, several sectors have experienced increases such as health, pharmaceuticals and telecommunications. The COVID-19 pandemic can be a momentum for the revival of the sharia economy as long as all sectors in it, both commercial finance, social and halal business, are capable of transforming into a digital-based sustainable sharia economy to meet the needs of the community, which continues to dynamically change amid the COVID-19 pandemic.

Indonesia is a paradise for halal products by being the highest consumer in the world. As reported by the Global Islamic Economy Report from 2013 to the present. Business opportunities are wide open and this provides opportunities for entrepreneurs of food and beverage products to gain big profits. Halal culture shows a trend. Even though so far halal certification has been running slowly but has shown a positive and significant effect on the increase in halal products.

Barriers and challenges always exist in the business world, and they are an inevitable part. But with an optimistic attitude, the intelligence to read the right opportunities and solutions, all these challenges and obstacles will be overcome. The desire of business people to get big profits in bad ways, namely by selling

77 Alvien Septian Haerisma, "Pengembangan Pariwisata Halal Di Indonesia Tinjauan Etika Bisnis Islam,” Al-Mustashfa: Jurnal Penelitian Hukum Ekonomi Islam 3, no. 2 (2018): 153-68. 
haram products will lose trends, customers and will ultimately harm themselves. So providing halal products is part of business needs, no longer an option. The role of the government which is now contained in the JPH Law will be to provide the best solution for halal business opportunities, if it is carried out well and immediately realized. Socialization to the community, and making them aware that they are an integral part of making halal a lifestyle for both Muslim and non-Muslim communities. For companies, if they don't want to lose customers, they must be able to read the opportunities by making halal certification part of excellent service or excellent service.

\section{References}

Agus, Panji Adam. "Kedudukan Sertifikasi Halal Dalam Sistem Hukum Nasional Sebagai Upaya Perlindungan Konsumen Dalam Hukum Islam.” Amwaluna: Jurnal Ekonomi Dan Keuangan Syariah 1, no. 1 (2017): 150-65. https://doi. org/10.29313/amwaluna.v1i1.2172.

Ali, Muchtar. "Konsep Makanan Halal Dalam Tinjauan Syariah Dan Tanggung Jawab Produk Atas Produsen Industri Halal." AHKAM : Jurnal Ilmu Syariah 16, no. 2 (2016): 291-306. https:/ / doi.org/10.15408/ajis.v16i2.4459.

Al-Ghazali, Imam, 2002, Benang Tipis Antara Halal dan Haram,Surabaya: Putra Pelajar

Amalia, Rizki, Strategi Negara Anggota IMT-GT (Indonesia, Malaysia, Thailand Growth Triangle) Dalam Pengembangan Industri Halal, Universitas Riau, 2015

Arif, Zainal. "Bisnis Produk Halal Antara Peluang Dan Tantangan, Problematika Dan Solusinya” 20, no. 1 (2020): 274-94. https:/ / doi.org/https:/ / doi.org/10.30603 / au.v20i1.1170.

- "Optimalisasi Peluang Dan Tantangan Ekonomi Islam Dalam Menghadapi Masyarakat Ekonomi Asean.” Al Maal: Journal of Islamic Economics and Banking 1, no. 1 (2019): 89. https:/ / doi.org/10.31000/almaal.v1i1.1817.

Arifin, Ahmad Yusro,2011 "Urgensi Sertifikasi Halal Bagi Upaya Perlindungan Konsumen di Indonesia”, Skripsi, Fakultas Hukum, Universitas Islam Insonesia.

Astuti, An Ras Try, and Rukiah. "Bisnis Halal Dalam Perspektif Etika Islam: Kajian Teoritis.” Al Ma' Arief: Jurnal Pendidikan Sosial Dan Budaya 1, no. 2 (2019): 14256. 
Azhar, Saifuddin, Sikap manusia; Teori dan Pengukurannya, Yogyakarta: Pustaka Pelajar, 2009

Badan Pusat Statistik, Sensus Penduduk 2010; Penduduk Menurut Wilayah dan Agama yang Dianut, www.bps.go.id

https: / / doi.org/10.15642/islamica.2017.11.2

Bahri, Efri Syamsul, and Zainal Arif. "Policy Analysis of Zakat Profession in Indonesia” 2011, no. 29059 (2020): 29059-67.

Bramantoro, Toni, Bisnis di Sektor Halal Lifestyle Saat Ini Memiliki Potensi Sangat Besar kata Sapta Nirwandar, tribunnews.com

Departemen Agama RI, 2003, Pedoman Fatwa Produk Halal, Jakarta, Departemen Agama RI

Eka Dewi Satriana Hayyun Durrotul Faridah. "Wisata Halal: Perkembangan, Peluang, Dan Tantangan." Journal of Halal Product and Research (JHPR) 01, no. 02 (2018): 32-43.

Ekonomi, Jurnal, Perbankan Syariah, Analisis Komparatif, Bank Umum, and Syariah Sampel. "Dampak Pandemi Covid-19 Terhadap Manajemen Industri Perbankan Syariah: Analisis Komparatif,” n.d., 1-10.

Faidah, Mutimmatul,” Sertifikasi Halal Di Indonesia Dari Civil Society Menuju Relasi Kuasa Antara Negara Dan Agama” Islamica, Volume 11, Nomor 2, Maret 2017

Fithriana, Arin, and Rendy Putra Kusuma. "Implementasi Kebijakan Pangan Halal Indonesia: Keunggulan Kompetitif Dalam Tren Pangan Halal Di Asia Tenggara.” Global Insight Journal 03, no. 02 (2018): 1-18.

Haerisma, Alvien Septian. "Pengembangan Pariwisata Halal Di Indonesia Tinjauan Etika Bisnis Islam.” Al-Mustashfa: Jurnal Penelitian Hukum Ekonomi Islam 3, no. 2 (2018): 153-68.

Handoyo, Potensi Besar Dari Bisnis Halal, Jakarta, nasional.kontan.co.id

Hidayah, Nur. "Covid-19.” In Covid-19 Wabah, Fitnah Dan Hikmah, 1:379. Amma Alamia, 2020.

Hidayat, Asep Syarifuddin, and Mustolih Siradj. "Legal Arguments of Halal Product Guarantee (Argumentasi Hukum Jaminan Produk Halal).” Jurnal Bimas Islam 8, no. 1 (2015): 31-66.

- "Sertifikasi Halal Dan Sertifikasi Non Halal." Ahkam : Jurnal Ilmu Syariah 15, no. 2 (2015): 199-210. https: / / doi.org/ 10.15408/ajis.v15i2.2864. 
Istikomah. "Peluang Dan Tantangan Implementasi Uu Jph (Studi Analisis Atas Uu No. 33 Tentang Jaminan Produk Halal).” At-Tasharruf; Jurnal Kajian Ekonomi Dan Bisnis Syariah 1, no. 1 (2019): 18-28.

Lembaga Badan Pusat Statistik (BPS), Mengapa Konsumsi Rumah Tangga Penting bagi Perekonomian, Kata Data News and Researcs, databoks.katadata.co.id

Mansyur, Mohammad A., Penegakan Hukum tentang Tanggung Gugat Produsen dalam Perwujudan Perlindungan Konsumen Naskah Disertasi Program Doktor Ilmu Hukumm Universitas Diponegoro, Semarang, 2004

Manullang, M. 2002. Pengantar Bisnis, Yogyakarta : Gadjah Mada University Press

Mashudi, Kontruksi Hukum dan Respons Masyarakat Terhadap Sertifikasi Produk Halal, Seri Disertasi, Pustaka Pelajar, LP2M UIN Walisongo, 2015

Mashuri, Ikhwanul Kiram, Kue Besar 'Halal Lifestyle' Jangan Diserobot Orang Lain, republika.co.id

Muhammad. 2004. Etika Bisnis Islam, Yogyakarta : UPP AMP YKPN

Munir, Misbahul, Akselerasi Tren 'Halal Lifestyle' indonesiana.tempo.co.id,

Muslich. 2010. Etika Bisnis Islami; Yogyakarta: Ekonisia Fakultas EkonomiUII

Nurdin, Nasrullah. “Bisnis Wisata Halal.” Dialog 42, no. 1 (2019): 107-10.

Opatija, World Halal Day 2016: Produk Halal Kini Jadi Gaya Hidup Konsumen Dunia, Jurnal Kementerian Perdagangan Republik Indonesia, 10 November 2016

Pasal 29 UUD 1945, Materi Amandemen Pasal 29 UUD 1945 Bakal Diwarnai Perdebatan, hukumonline.com

Piagam Kerjasama Departemen Kesehatan, Departemen Agama dan Majelis Ulama Indonesia tentang Pelaksanaan Pencantuman Label Halal pada Makanan tanggal 21 Juni 1999

Purnomo, Dwi, Strategi Pengembangan Agroindustri Halal Dalam Mengantisipasi Bisnis Halal Global, Bogor, Disertasi Institut Pertanian Bogor, 2011

Rahmadia, Shinta, Nurul Febriyani, Universitas Syiah Kuala, Jurusan Ekonomi Islam, and Universitas Syiah Kuala. “Dampak Covid-19 Terhadap Ekonomi,” 2020.

Rahman, Fazlur, Islam dan Modernity: Transformation of an Intelectual Tradition, Chicago \& London: The Uviversity of Chicago Press, 1984

Rahmayani, Dwi, Peluang Emas Membidik Bisnis Makanan Halal Global, www. coreindonesia.org 
Reuters, Thomson, State of the Global Islamic Economy 2014 - 2015, Dubai The Capital of Islamic Economy, Dubai 2014/2015

Rohman, Abdul, 2012. Pengembangan dan Analisis Produk Halal, Yogyakarta: Pustaka Pelajar

Siahaan, Saribua, Peluang Investasi di Sektor Farmasi Indonesia, Indonesia Investment Promotion Center (IIPC) Tokyo, 2017

Sofyan, Riyanto, Prospek Bisnis Pariwisata Syariah, Jakarta: Republika, 2012

Waharini, Faqiatul Mariya, and Anissa Hakim Purwantini. "Model Pengembangan Industri Halal Food Di Indonesia." Muqtasid: Jurnal Ekonomi Dan Perbankan Syariah 9, no. 1 (2018): 1. https:// doi.org/10.18326/muqtasid.v9i1.1-13.

Warta Ekspor, Hidup Sehat dengan Produk Halal, Jurnal Kementrian Perdagangan Republik Indonesia, Ditjen PEN/WRT/56/VII/2015, Edisi Juli 2015

Wiranata, Gede A.B, Etika, Bisnis dan Hukum Bisnis, Bandar Lampung: Universitas Lampung, 2010

Yulia, Lady. "Strategy Strategi Pengembangan Industri Produk Halal." Jurnal Bimas Islam 8, no. 1 (2015): 121-62.

Yusanto, Muhammad Ismail dan Widjajakusuma, Muhammad Karebet. 2002. Menggagas Bisnis Islami, Jakarta: Gema Insani Press

Zenefale, Trend Global Produk Halal Menjadi Gaya Hidup Negara-Negara Non Muslim, Artikel 13 October 2015 